\title{
Hosier and Rutledge Lanes-where anyone can go and make art and other stories
}

Debbie Qadri

\begin{abstract}
Hosier and Rutledge Lanes in Melbourne are concentrated areas of street art, widely understood as places where anyone is free to add art to the wall. During a group installation to celebrate International Women's Day, the lanes revealed their darker sides, challenging the author's rosy view. This encounter led research to find other stories of the lanes in relation to inclusion and exclusion. The lanes revealed themselves as a place where current issues and contradictions of public life and public art are brought into the spotlight. Because Hosier and Rutledge lanes are controversial sites of beauty, fame, and vice they draw the limelight of the media and act as pedagogical sites which stimulate debate and argument.
\end{abstract}

\section{Keywords}

street art; public art; methodology of narrative 


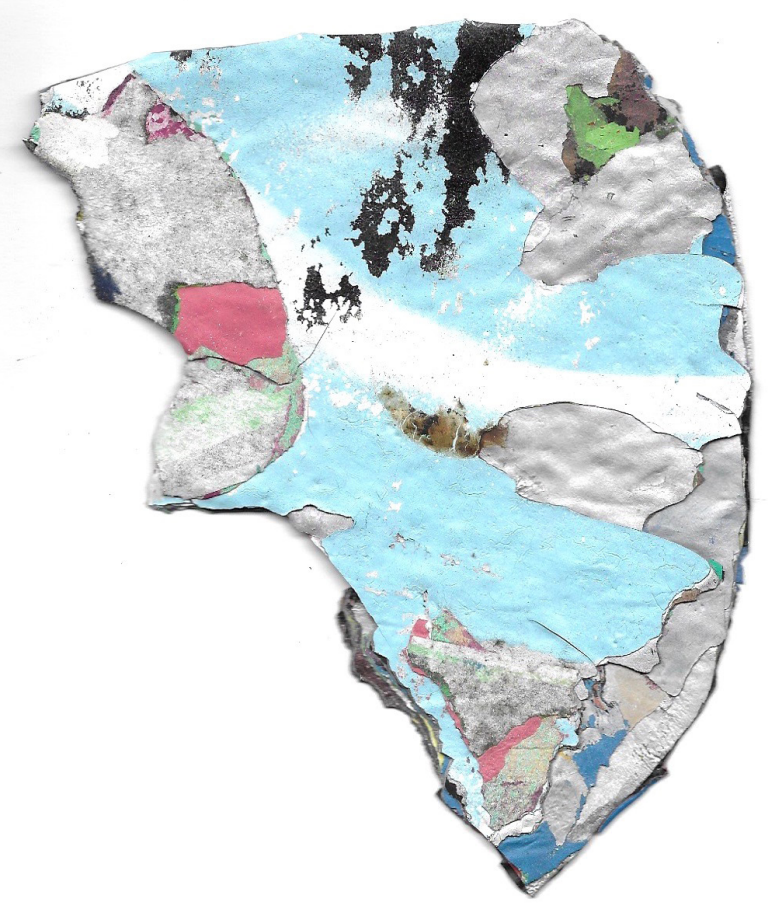

Fig 1. My piece of 'Hosier Lane'

\section{Introduction}

I treasure my piece of 'Hosier Lane'-a slab of paint I peeled from the wall one day. Whilst only two mm thick, it contains hundreds of layers of aerosol paint—and for me was symbolic evidence that Hosier and its adjoined counterpart Rutledge Lane are extraordinary places where everyone is free to go and make art on the wall. Enamoured with the lanes, I viewed them as powerful protagonists for graffiti and street art. But recently, when I went there to install art with a group of women, the lanes revealed their darker sides, challenging my rosy view.

Using the methodology of narrative (McAlpine 2016), I have found and retold stories of the lanes, and included my own stories in italics. I began by finding stories of 'exclusion' but also wanted to find out how the lanes contribute to our understanding of public space (Hickey 2010). I discovered them to be very public pedagogical sites which stimulate debate and argument. Their popularity as a tourist destination and a place for artists to install, assists Hosier and Rutledge lanes to draw the limelight of the media, thus magnifying and drawing a wide audience into the current issues of public life which unfold in the lanes.

Like all narratives about public art and public space, these stories involve questions such as: whose space is this? and what rights do we have within it?

'Access to public space is important because these spaces serve as physical arenas for democratic actions. . . graffiti serves the vital function of communicating grassroots ideas, sympathies, and demands' (Conklin 2020, p.157). 


\section{The place-Hosier and Rutledge lanes}

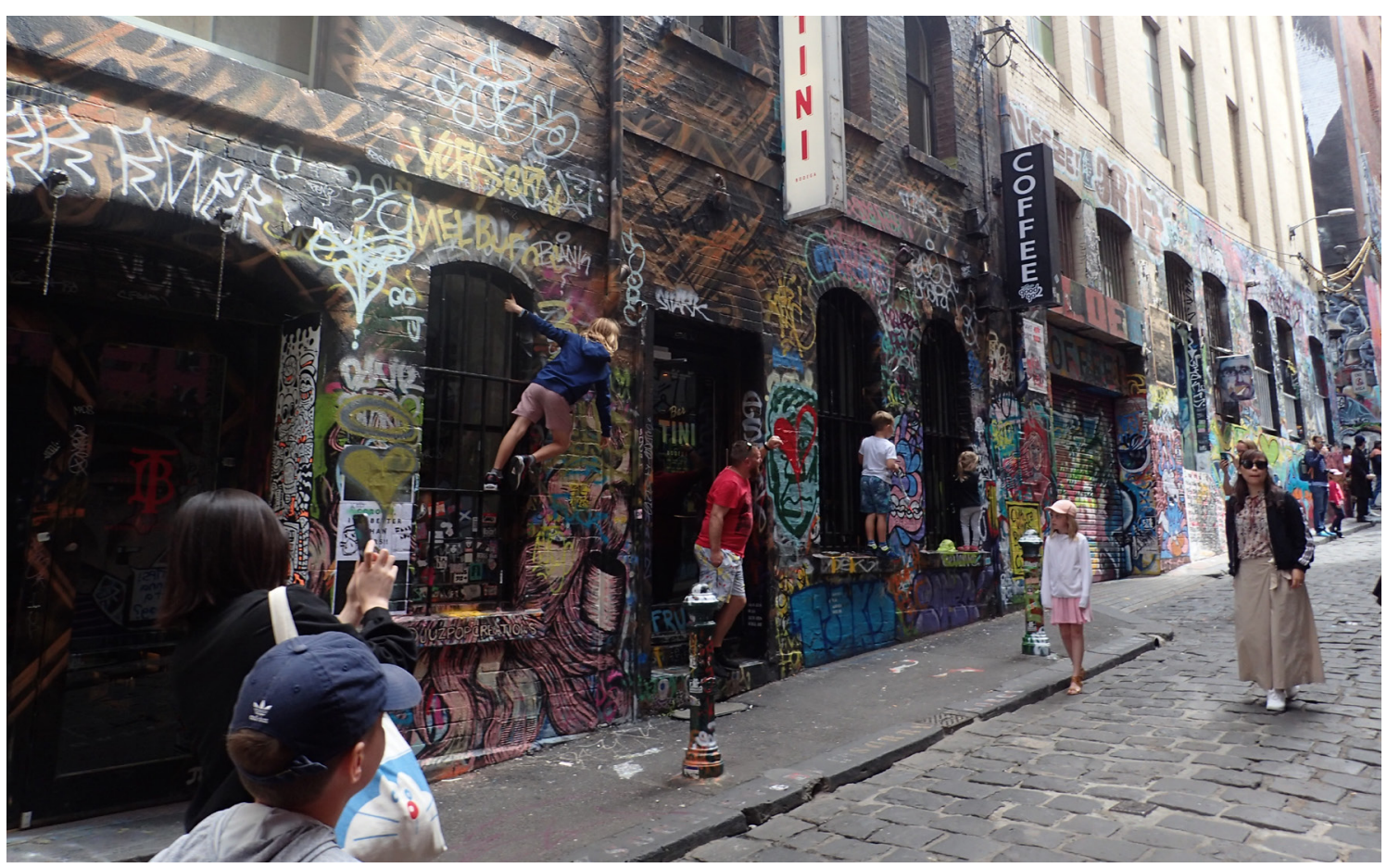

Fig.2: Photograph of Hosier Lane

Hosier and Rutledge Lanes present a place of concentration of street art, where every reachable wall surface is covered in an ever-changing medley of street art and graffiti. In these lanes, graffiti and street art are passively allowed without permit and not removed. This has caused an understanding by the broader public and many artists that anyone can come to the lanes and put art on the wall without being penalised.

I did install some artwork myself, in Hosier Lane, firstly in 2014 as part of a Fringe Festival project which I enjoyed, though I noticed that my work was soon sprayed over. In around 2015 I installed some other work for which I wanted to remain anonymous, and this changed my experience of the lanes. I felt compromised by the many tourists around me taking photographs.

But I still loved the lanes and often took visitors to show them the area with pride. 


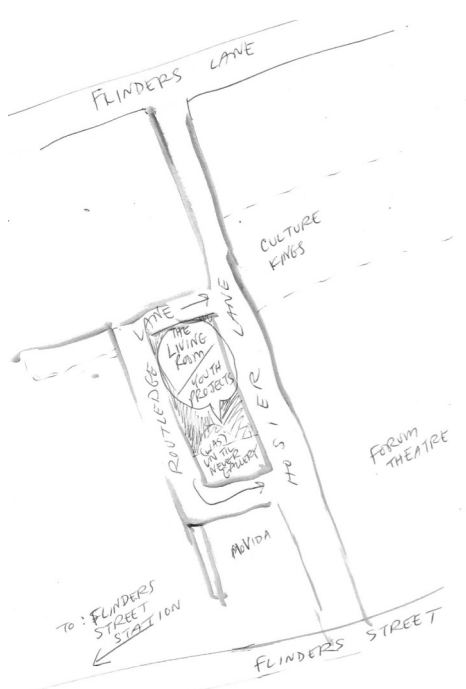

Fig. 3: Map of Hosier and Rutledge lanes

The street art and graffiti have created an aesthetic surface over the buildings creating an attraction for tourists. It is often full of people taking selfies and tourists. and wedding groups

'Hosier and Rutledge Lanes function as a spectacle: there, street artists work in broad daylight, with the time to develop their practice' (Hilary and Sumartojo 2013, p. 214).

The situation has placed Hosier and Rutledge lanes at the cusp of the relationship between street art, graffiti, government and the public.

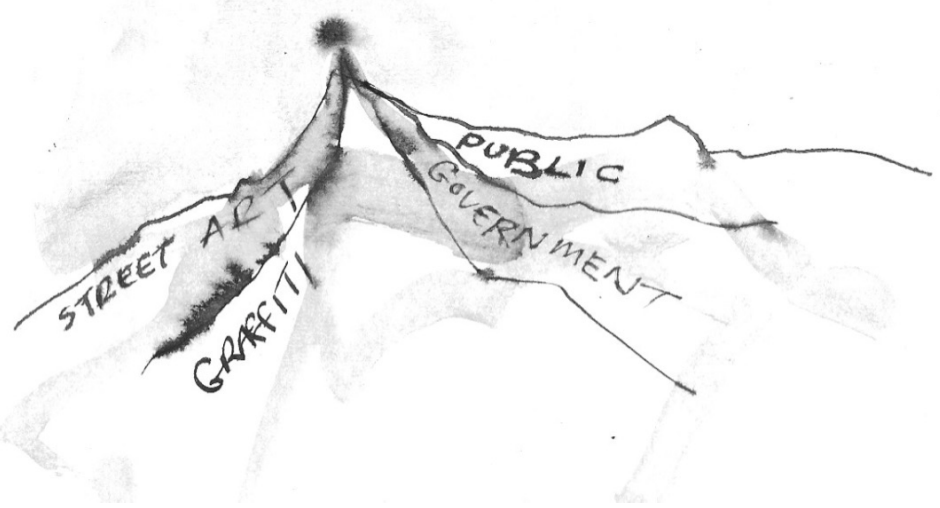

Fig. 4, The cusp between street art, graffiti, government and the public

Jopp (2017) describes it as Melbourne's love-hate relationship — the difficulties being that what is arguably one of Melbourne's top tourist draw-cards is created by illegal activity. In particular Hosier Lane is a place where things come together at a point which could tip either way. Events that happen in the lanes are often amplified, argued, debated and obsessively documented in media, social media and in the physical space. The lanes provide a focus on current issues and responses to street art and graffiti but are also interconnected with other other aspects of the urban ecosystem and real world problems (Holsworth 2016).

'Looking at street art and graffiti keeps raising a wide variety of real issues; issues like private and public property, freedom of speech and currently, homelessness' (Holsworth 2016). 

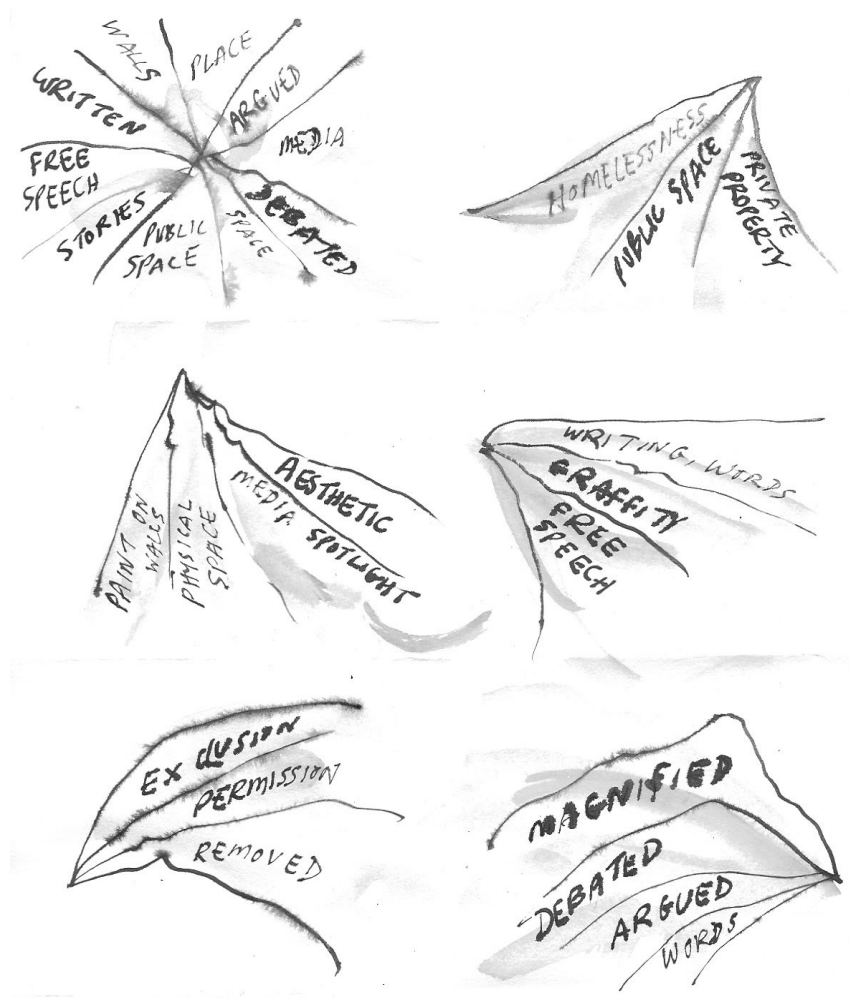

Fig.5: A place where things come together at a point which could tip either way.

\section{The International Women's Day install}

A collective of women have been regularly installing artwork in Hosier Lane to celebrate International Women's Day. This year I was invited to join in. While we did the installation I interviewed some of the participants for a podcast-'Feminist Voices At Hosier Lane' (Qadri, 2020). This allowed me to reconnect in a deeper way with the lanes.

There is the slip slop of the glue in the bucket and the sounds of a paintbrush brushing the wall. We can hear the sounds of children, parents and partners here, even grandparents discussing where and how to install the artwork. There are also the sounds of tourists and visitors to Hosier lane, and other noises such as birds, the bells of St Paul's nearby and planes flying overhead. There's also the booming music from the retail outlet Culture Kings, which has an entrance opening out into Hosier Lane. At times I can also hear the clink clink and

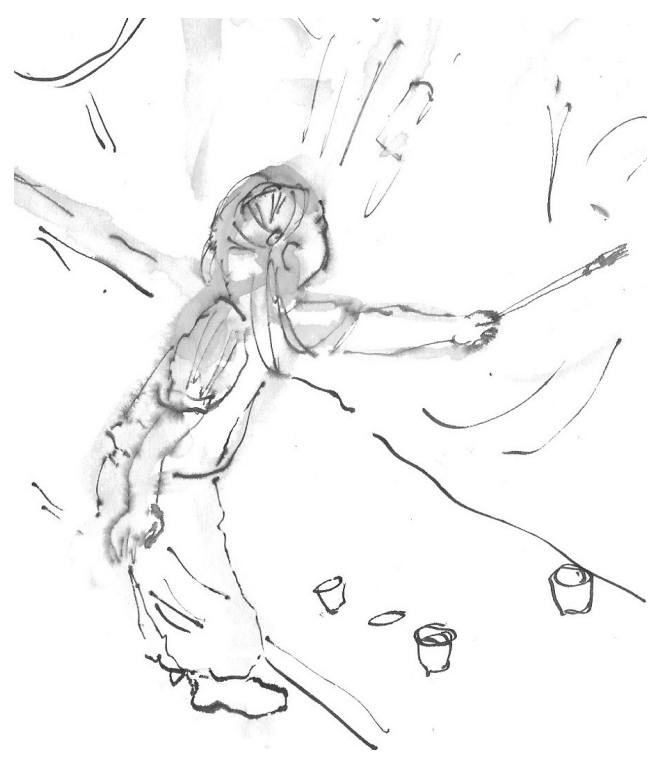

Fig. 6: Child painting Hosier Lane as part of the International Women's Day Installation spray of an aerosol artist in the laneway.

Through the act of documenting this installation with my recorder and camera, I encounter other people's perspectives. Issues are raised about the widely assumed accessibility of Hosier Lane. Some of these things are surprising to me. 
It was the group gathering and also the idea that anyone can place art in the lanes which made the International Women's Day install possible. The choice to install in Hosier Lane was because of its high visibility and that we are unlikely to be prosecuted.

'The space is one of the few spaces in Melbourne where you can come and you're not get into any trouble for posting work in public.' (interviewee on podcast, Qadri 2020)

Through the interviews I learned that legality and safety are issues which concern women and which likely prevent them from regularly making street art or graffiti. Not everyone felt safe to install in Hosier Lane and some said they would never have installed alone. Many of the participants had never previously installed art in public space before and said they would not normally do so. Gender seemed to affect decisions to make art in public space for a range of reasons.

In Hosier Lane we felt free to take our time and to install during daylight and children and families could also be more easily involved. Some participants told me that it was not legal, and that there were risks associated with installing. The ever clicking cameras of tourists also affected some of the installers, making them uncomfortable about where the photos might end up. For some installers, The close circuit tv cameras provided an extra reminder that what we were doing was not legal.

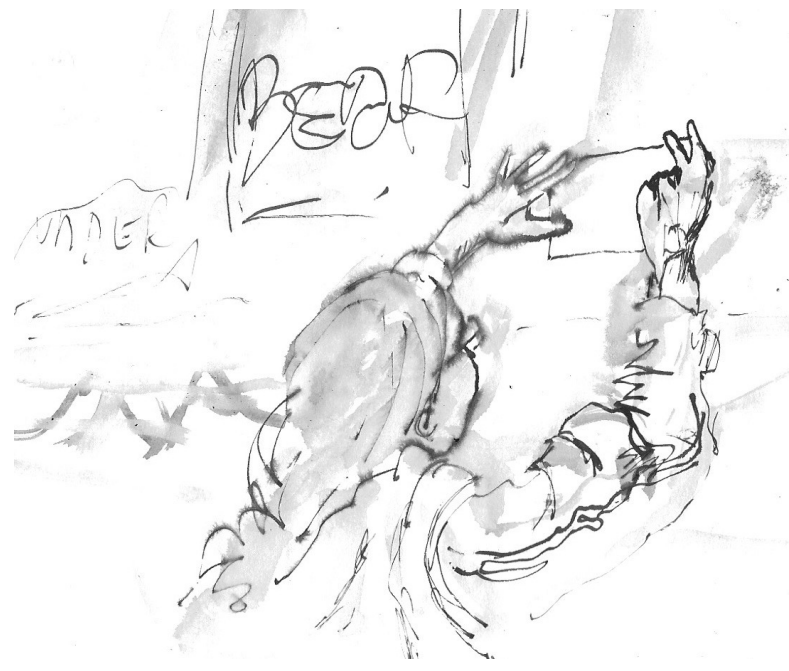

Fig. 7 , pasting up as part of the International Women's Day Installation

I was also told the story of the first time that some of these women had installed in Hosier Lane, which had made them more determined to install in Hosier Lane annually.

A couple of years ago, we put up a work ... that was done by a crew in Wellington, an anti rape banner, and we put it up right here where we are painting today and some street art boys came and defaced it in a really degrading way, so it became a pro-rape banner after their work. So we are just really sick of how boys-ey the street art work in Melbourne and internationally is and so wanted to kick back against it. So after that day (that they did the defacing), we came with a crew on International Women's Day... and did just a heap of paste-ups and installations and painting' (Interview with installer, Qadri 2020).

The group have been coming annually on International Women's Day ever since. The above interviewee said she felt the lane had a 'pissing on walls, marking territory feel about it' and this may have been coloured by her experiences of the laneway. 
I found a really important part of this group install was the ongoing discussions about each installation, in regard to the methods of installing, but also how the meaning and information held in the artworks could be conveyed. There were also conversations with other people in Hosier Lane who asked what we were doing and ensuing discussions about the subject matter and meaning of the artworks.

The installation was so much more than I imagined. I had this strange insight into the many ways in which Hosier Lane is not as accessible as I thought, and aspects of street art culture which might explain the low percentage of female street artists and graffiti writers (Vittorio Parisi, 2015).

I also found out how very important gathering together is which was the catalyst for many of the women to install artwork in the lane.

The lanes were contradictory and complicated in the way they allowed access to install artwork but also inhibited it. The interviews with the installers on International Women's Day drew me into examining the lanes more closely through the lens of exclusion.

\section{History of Hosier Lane as a graffiti space}

Mundell (2019), describes how the laneways in Melbourne's CBD were never planned but began to grow unofficially in response to needs - the night cart man, back entrances for staff to use and where 'the grunt work could be discreetly carried out' (ibid p.3). 'Shanty towns sprang up in some lanes, while others became home to stables, brothels, laundries, opium dens, boarding houses, or artisans' workshops' (ibid, p.4). Mundell describes those in power trying to create an image of order which the back lanes threatened.

In 1998 Hosier Lane was graffiti free (Mundell 2019, p.8: Arbus 2010), but by the early 2000 s a street art movement in Melbourne was underway. Sean Irving remembers the emergence of the street art scene in 2004:

'Hosier had an enduring appeal for a number of reasons: its proximity to Flinders Street station, the presence of Andy Mac's Until Never Gallery (an early champion of the work as an art form) in the lane, and the fact that artist's had studios in the area (including $\mathrm{Ha}-\mathrm{Ha}$ and Adrian Doyle of Empty Nursery Blue fame). For myself and my friends it was an unregulated space, a haven where we could hang out, drink, and paint without being disturbed. Essentially everything you want as a teenager. It was a formative destination' (Irving, no date).

Hosier Lane was partly curated by Andy Mac over many years. He established the City Lights program in 1996, a series of lightboxes which drew visitors and contributed to the development of the lane as 'the epicentre of Melbourne's illicit art scene' (Young 2016, p. 175). Andy Mac also encouraged artists to paint the walls (ibid).

By 2006 Melbourne was represented through various media and organisations as a street art capital (Mundell 2019, p.8). And in reaction to the movement:

'In 2006 the State government ran a 'zero tolerance' graffiti crackdown, with steep fines, expanded police powers, and potential jail time (Mundell 2019, p. 9)

Amidst the contradiction of Melbourne being hailed street art capital and an increasing crackdown on graffiti, street art permits were able to be issued for the first time in 2007. Many permits were issued for Hosier and Rutledge Lanes, including retrospective permits 
to protect artworks which had the unintended consequence of appearing as if they were legal walls for painting and very quickly the walls became crowded with artwork (Young 2016).

Images of Hosier Lane from 2010 (Browne 2010, Holsworth 2020B) show artwork in Hosier Lane is more organised and less chaotic than it is at the time this article is written).

In 2010 a Bansky stencil (d.2003) which was in Hosier Lane on the Forum Theatre building was damaged by cleaners (Mundell 2019; Browne 2010). There followed a media storm which generated debate about the protection of significant graffiti and street art (Browne 2010).

'Up until this point the only substantive response to graffiti by State and Local Governments had been to remove it' (Browne 2010, p.6).

This led to state arts ministers vowing to protect the unique heritage of Hosier Lane (Mundell 2019) and according to Browne (2010), it 'marks a clear turning point in the requirements of graffiti policy'(p.6). Illegal art had now gained cultural value and authorities had to tread the fine line wavering between removal and protection. An unclear, uneven and wavering edge between vandalism and cultural value. A place where they are forced to meet and negotiate.

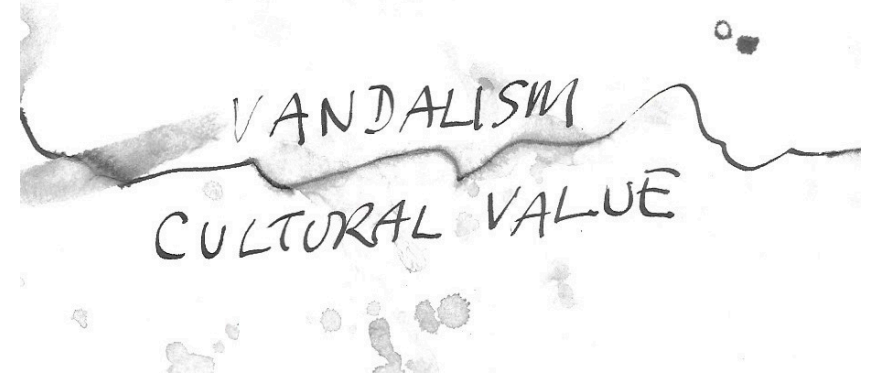

Fig 8. The unclear, uneven and wavering edge between vandalism and cultural value.

In it's Graffiti Management Policy (2009-2013), the City of Melbourne incorporated acknowledgement that street art has cultural value for young peopleadvocating for areas in the city which will have a high tolerance for street art and graffiti, and advocating permits and programs to create more opportunities for legal works (Browne 2010). Browne (2010) discusses the changes in graffiti policy which eventually led to the city of Melbourne creating (not policy but) practice of curatorial-ship in Hosier and Union lanes where the graffiti and street art were 'protected by Municipal management, (that is, Council's cleaners know not to remove the works)' and were 'curated by individuals with extensive prior street art experience (p. 32)'. Browne noted that 'curatorial expertise is instrumental to the high standard of output at these sites', and entailed ongoing programs.

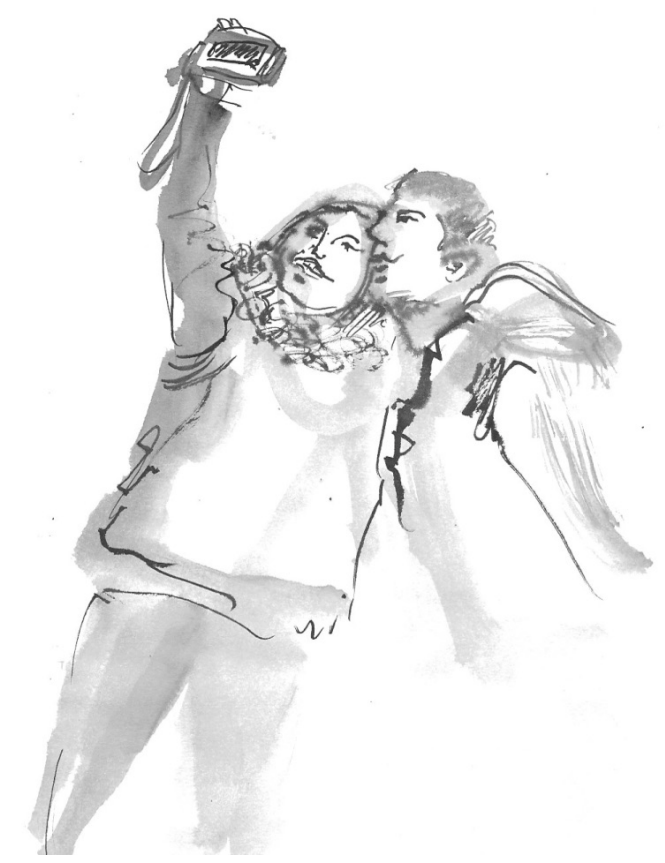

Fig. 9: Tourists creating selfies 
Mundell (2019) suggests that since 2010 government and business interests have focussed on Melbourne's laneways and their street art as a tourist attraction, which has led the the artwork on the lanes holding economic value. Tourism has attracted the interests of more powerful stakeholders in the lane who have an increased economic and legal clout.

Certain types of imagery are imagined as more attractive to tourists. CDH (2013) explains that often what is valued in street art is artwork similar to mass media imagery. An example he gives (for evidence of this value) is that one of the few artworks in hosier lane to be repaired was essentially a reproduction of a movie poster image of Heath Ledger (CDH, 2013). It also brings to mind the large mural of cricket player Ellyse Perry, which was created in Hosier Lane as an advertising campaign for a cricket tournament.

Mark Holsworth also draws us to consider the com-

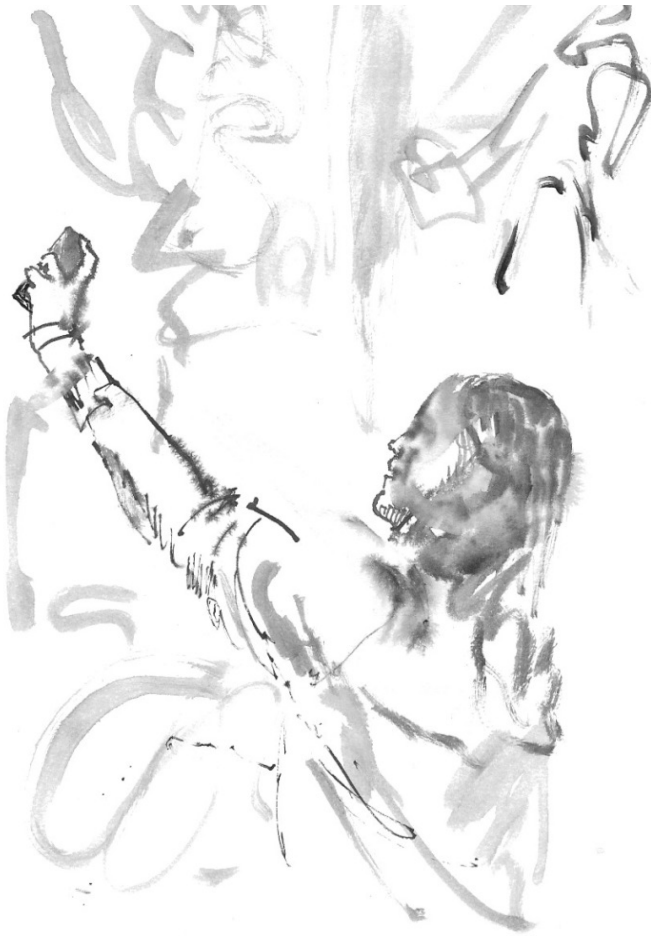

Fig. 10: tourist taking photograph of laneway art mercial undertones of Hosier Lane -pointing out:

'graffiti writers and street artists have all these commercial projects- $t$-shirts, leading walking tours, exhibitions and commissions. And a few metres up the lane, the shop Culture Kings has made a massive hole in the lane's famous walls to provide access for buyers of their shit' (Holsworth, 2020A).

\section{Inclusion vs exclusion-Perceptions of safety and atmosphere}

I think what people like about Hosier Lane is that we imagine its accessible to all.

Edward Soja (2009) argues that we should consider spaces in terms of how they cause justice or injustice and how spaces relate to ideas of democracy and human rights. He refers to the 'social production of spatiality' - the idea that 'space is socially produced and can therefore be socially changed. Secondly he refers to the 'socio-spatial dialectic (the spatial shapes the social as much as the social shapes the spatial) $(2009$, p.2)'. There are spatial and physical aspects of space which relate to social uses of space.

Some exclusion and inclusion is physically organised, for example in 2017 and 2018 Hosier Lane was been taped off so that people could attend parties in the lane where tickets cost over $\$ 100$ each. The police can physically remove homeless people and their belongings and the entrances to their sleeping areas can be boarded up with materials. Physical actions of inclusion or exclusion are often made possible by legal acts, permits, policies, laws and police intervention which unfold in some people being allowed to make art in the lane whilst others will be pursued with fines and jail time. In the UVM-Sustainable Urban Ecologies Report of 2010, it was noted that Hosier lane is not physically accessible for many disabled people, and that one of the footpaths needs to be widened to allow wheelchair access. This remains an issue. 
Other less palpable indicators of inclusion or exclusion are revealed in how people describe their perceptions of the atmosphere which I first discovered through my interviews with the installers on International Women's Day. A perception of danger might exclude some people from entering places, for example street art and graffiti effect how we mentally perceive public space (Gralinska-Toborek, 2016).

In 2013 Fiona Hillary and Shanti Sumartojo curated a series of public artworks in the laneways to 'activate the space and explore the relationship between public art and public safety' (Hillary \& Sumatojo 2014, p.2). These included street art mural commissions including Adrian Doyle's Empty Nursery Blue, in which he covered Rutledge lane and its cobblestones in blue paint. One of the project's aims was to 'shift people's perceptions of the space and sense of safety' (ibid,. p.2). An inference that can be drawn from this is that choosing to access a space in regard to safety is about perception, instead of physical realities or likelihood of events. These are un-quantifiable aspects, based on the judgments and feelings of individuals.

Hilary and Sumartojo also explain that atmosphere is not fixed or set, it is always in flux, moving and transforming and also depends on the person's relational experience-how they individually apprehend the space (p.208).

By installing together as a group on International Women's Day, we felt safe, affirmed and supported in each others' company so our apprehension of the place was affected positively. Alternatively the experience of the first installation by some of the women, where the artwork was later altered by others to make it into a pro-rape artwork, will remain as a negative experience of the lanes accompanied by anger and sadness.

A survey of media articles and blogs also confirms that the perception of safety in the lanes changes continually. In 2016 a post by Hosier Lane Inc. suggests that artists were 'not safe —regularly threatened, attacked and robbed' (Hosier Lane Inc, 4.10.2016) and there were less works by notable artists and more tagging and 'vandalism'. The writer suggests as a last resort - presumably to solve the safety issues - that the laneway should be completely buffed or graffiti removal policy implemented. This raises the spectre of the 'broken windows' theory - the idea that permitting minor forms of public disorder (such as unauthorised artwork and writing) encourages more serious crimes (Conklin 2020).

\section{Homelessness and street art}

'Hosier Lane is infested with the ghosts of the repeatedly evicted street dwellers' (McKinley 2006).

In late 2005 the City of Melbourne began cleaning up in readiness for the commonwealth games. Artists Nic Low, Stephen Mushin, and Jim Moynihan responded in 2006 with an artwork called Clean (Low 2006). The artwork was a series of audio files which championed the city's homeless people and graffiti artists, both of whom had been made more unwelcome than usual in readiness for the Games' (McInley 2006). Standing in certain places in Hosier Lane would cause the audio files to play. Apart from being about the disenfranchised people who were cleared from the city, the artwork is also an expression of the relationship between the artists and homeless people whose voices they include in the artwork.

'Melbourne's homeless generally have a positive attitude towards street art and graffiti.

And the street artists and graffiti writers are generally supportive towards the homeless' (Holsworth 2016). 
In 2016 there was increased media attention on the problem of homelessness in Hosier and Rutledge Lane and this seems to have come after The Living Room, in Rutledge lane, was renovated and re-launched. The Living Room provides services for homeless people including: medical care, contraception, legal advice, clothes washing, showers, internet access and mail services. Problems for rough sleepers in the lane also worsened when alcoves were boarded up as part of demolition work on the old Russell Street Theatre that backs onto Hosier Lane' (Holsworth 2016A). Francis (2017) reports that boarding up the alcoves in the lanes affectively displaced about 20 rough sleepers.

These events were also documented by street art writers/artists in ways which suggested intrinsic connections between rough sleepers and the artwork in the Lanes (Honig 2017, Holsworth 2016). A restoration action was undertaken by a hip hop group Combat Wombat where they filmed themselves cutting doors into the boarded up alcoves (Combat Wombat 2016).

Many artists, writers and music makers support rough sleepers and there are likely to be deep reasons for this, which are not readily apparent. When I was researching the Great Wall of St Kilda mural I discovered that below its surface which celebrates the places and community of St Kilda, the origins of the artwork were a response to the removal of rough sleepers from the park where it stands (Qadri 2019). Rosalyn Deutsche (1996) also draws the homeless into her examination of art in public space. She warns that the presence of homeless people is a symptom of uneven social relations and suggests that public art programs (which partner with urban development, architecture and urban design), often create sites which suppress the social conflict in the space. Deustsche (1996) argues that the homeless person is constructed as an idealogical figure who brings the conflict with them, instead of recognising that conflicts exist as inherent aspects of public space.

Perhaps the affinity between artists who work in the street and rough sleepers is that both are blamed for conflict. Chris Honig (2017) is interested in how rough sleepers are seen negatively but often contribute to the city in unexpected ways. He says 'A repeated argument deployed to displace people experiencing homelessness from Hosier Lane has been that their presence may adversely interfere with tourism' (2017). We see these arguments in the media, that tourists should be prevented from having to witness the daily activities of rough sleepers. As Holsworth points out, the homeless do what many Australians do in their houses, but if you are rough sleeping, then you have to do those same things on the street (Holsworth 2016). Whilst Honig documented the laneways over eight months, he discovered that at least twelve homeless people regularly painted in Hosier Lane and contributed up to $20 \%$ of the artwork on the walls. In this way they were actively contributing to the tourist attraction of the Lanes.

Street art within the city is known to go hand in hand with gentrification and the gradual exclusion of people of lower socio economic means. These processes often include efforts to remove rough sleepers.

In particular in Hosier lane, the street art has attracted tourists, which has created an urge by authorities to protect economic interests in the area and remove rough sleepers. On the other hand, the rough sleepers are home and they participate in making the art that threatens their opportunity to stay 'home'. This suggests a circular process except that the rough sleepers are removed and the circle/cycle unravels. 


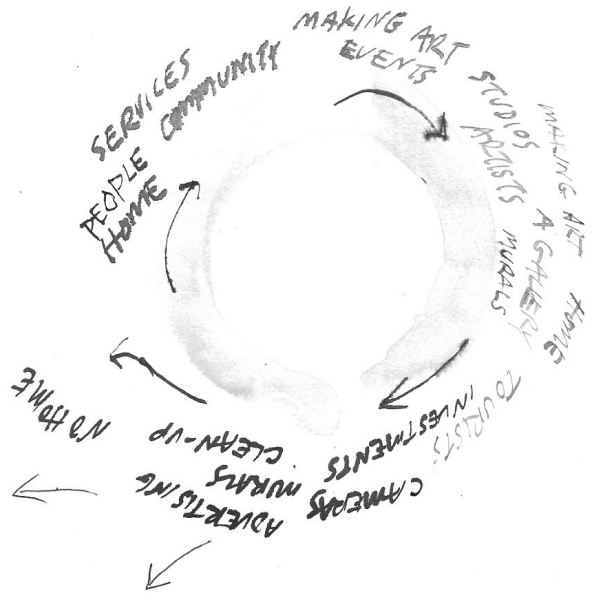

Fig.11: An unravelling circle/cycle of interconnections

The Living Room has been in the lanes and providing services to rough sleepers since 2001. This also explains why Hosier and Rutledge Lanes are 'home' to many rough sleepers. Like a chicken and egg argument it might be considered that the lanes' status as an internationally renowned street art and graffiti area originated from the presence of the rough sleepers and the young people who frequented the area because of the support services and Youth Projects (and who made the lanes their home).

Trawling through articles which feature the Lanes I came across a photograph which encapsulates this idea of home in the lanes. It is a photograph of thirty people seated on a long table that fills half of Rutledge lane celebrating Christmas together.

\section{Ephemerality}

Exclusion happens every day to artists in Hosier and Rutledge lanes in the way that their artwork is covered over. Hilary and Sumatojo (2014) describe this as an 'urgent ephemerality' (p.209).

We felt the threat of ephemerality during the International Women's Day installation. There were discussions about where to place the artworks so they wouldn't be painted over or removed easily. Or should we place them at eye level so they had a better chance of being seen before being painted over. It is a high profile area but also a high turn over area. Nothing stays there for long.

I had designed my artwork to be three dimensional, so that it would remain seen even when painted over. I glued my work down low near the ground because experience has taught me it will be less likely to

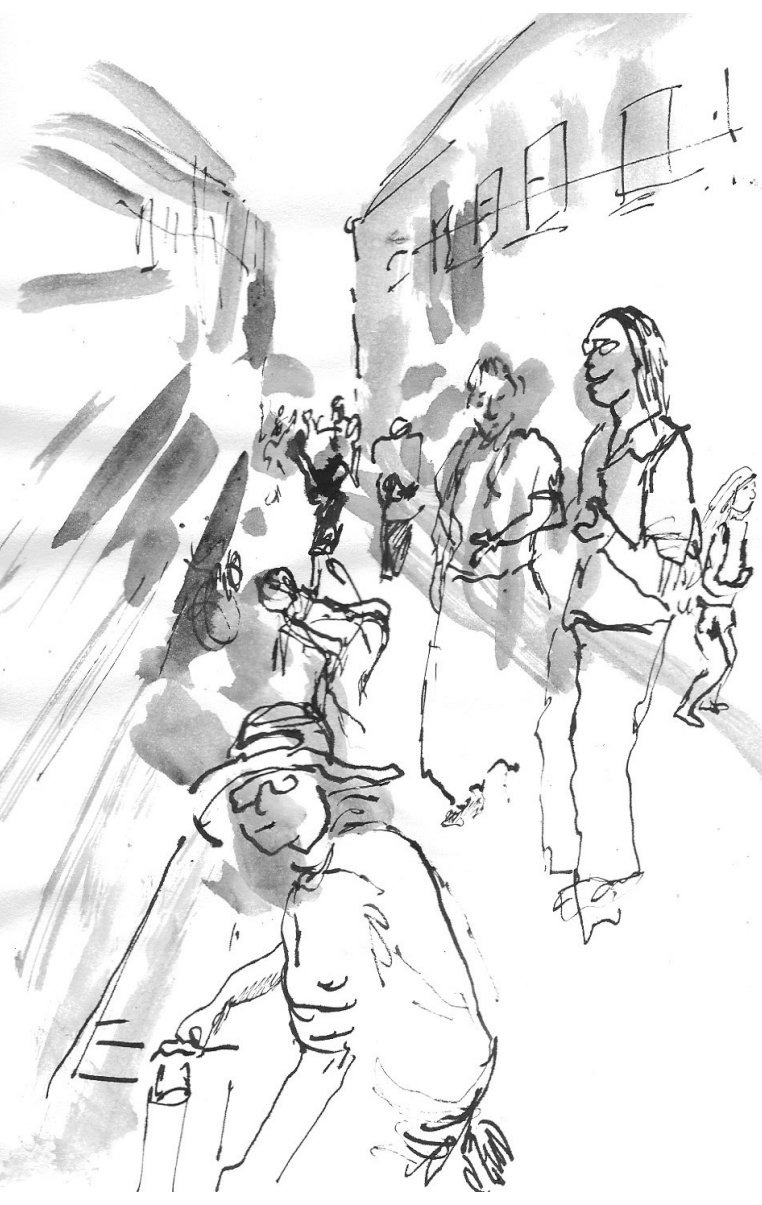

Fig. 12 Installing low to the ground, International be removed. 
Six hours after the installation, some of us returned to the lanes. We discovered that the aerosol artist who had been there at the same time as us, had almost completely covered one of our installations. This was ironic since the artist had placed her artwork carefully so that it did not cover ('cap') other artworks. It re-minded me that it was a dog eat dog place.

\section{Free to paint in Hosier lane and other stories}

In both Hosier and Rutledge Lanes it is not legal to mark the walls without the owner's permission, but in reality many people do so without consequence. And then others are suddenly pursued as vandals and criminals.

Some people are easily able to negotiate permits to place their works on walls because of their experience, status and contacts with those in power. Often the differences between permitted artworks and 'vandalism' are their legal status, not any difference between the aesthetic or intention of the works. In 2013 Adrian Doyle legally painted the cobblestones of Rutledge Lane entirely in blue. In 2020 I witnessed a child paint the cobblestones as part of the International Women's Day install, with no recrimination but earlier in the year painting the cobblestones had been considered an act of vandalism.

In August 2018 an artist had the police called on them for painting over one of the murals surrounding the Culture Kings entrance. Culture Kings later issued an apology.

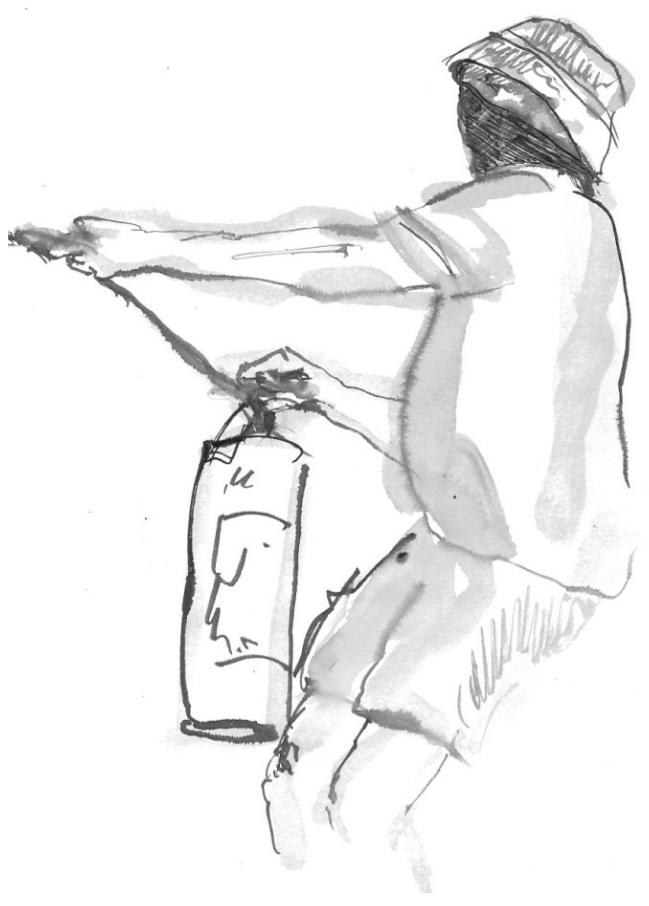

Fig. 13: Paint Bomber in Hosier Lane

In early 2020 a team of men armed with paint filled fire extinguishers and weed sprayers paint-bombed Hosier Lane. One of the participants said it was intended as an artistic and political statement-a call out to the hypocrisy of Melbourne City Council over street art and a statement against the commercialisation of street art (Miller 2020).

The paint-bombers effectively covered a large section of the lane very quickly with a splash and drip style of artwork not unlike the work of Jackson Pollock (Irving 2020). The instant obliteration of the work underneath, and the change in the aesthetic of the Lane provoked an angry response from officials (police and Melbourne City Council) who perceived it as vandalism and a criminal offence. Reasons given include: the damage to the cobblestones, the absence of permission and the disrespect and destruction of the works underneath (which were not in the spirit of Hosier Lane).

From my own experience of installing in the lane without permission I know that artwork can be capped very quickly, often within the day-and this ephemerality is the normal and expected evolution of the lane as it is continually overpainted. When I heard about the paint-bombing I immediately thought back to Doyle's Empty Nursery Blue and how it had 
also had capped existing works and covered the heritage cobblestones in blue paint. Many articles about Hosier and Rutledge lanes lead back to Empty Nursery Blue perhaps because it controversially destroyed so much artwork underneath and was such an extreme example of what you can do with permission. By looking more closely at my chunk of "Hosier Lane" and trying to split it into other layers, I remembered that in reality I had peeled it from Rutledge lane. I can now see that the pieces are riddled with Empty Nursery Blue. Perhaps sprayed more heavily and also through being acrylic instead of solvent based, it doggedly remains not only in memory but also its physical presence. My symbolic pieces of the lanes peeled off the wall at Empty Nursery Blue. It remains a powerful (and privileged) dividing point with the mass of blurred aerosol artworks merged together on either side.

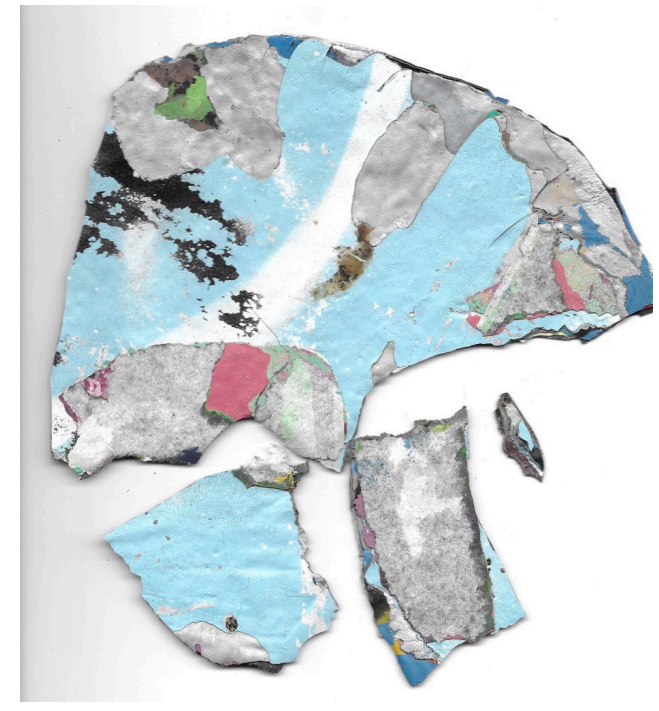

Fig. 14: Chunks of paint with Empty Nursery Blue.

Erin Buckley (2020) draws our attention to the parallels between the complete covering of Rutledge Lane in Blue paint and the paint-bombing of Hosier Lane. Both artworks serve the function of 'critiquing the nature of art, street art, the question of value of our relationships to public space', except one was authorised and the other was without permission. Empty Nursery Blue was part of a project commissioned by the Melbourne City Council which aimed to restore 'law-abiding foot traffic' and a 'decrease in antisocial behaviour in the area' (Young 2016). The paint-bombing, although being unauthorised, would have caused similar positive affects.

Back in December 2013, not long after Empty Nursery Blue, the National Gallery of Victoria organised a repaint of the entirety of Hosier and Rutledge Lanes, hiring 100 artists, as part of its Melbourne Now exhibition (Mundell 2019). Again a complete destruction of the works underneath (not in the spirit of Hosier Lane) and likely well-heeled foot traffic.

Both Doyle's Empty Nursery Blue and the work of the paint-bombers have drawn a mix of admiration and denigration.

Buckley argues that the differences between 'street art' and 'vandalism' were delineated by Melbourne City Council according to whether the artwork was 'unwanted' (Buckley 2020 B).

Buckley argues that the term authorised does not only mean explicitly commissioned, it might also refer to works which are encouraged (such as those in Hosier and Rutledge lanes) and works which are not removed. So we have reason to believe the claim by the paint bombers - that they believed Hosier Lane was free to paint in. Young also explores the idea that what is called street art as opposed to graffiti or vandalism depends on how it is 'liked' or considered 'beautiful' (2016, p.33-34). Irving (2020) says undoubtedly the main issue with the paint-bombing was the 'erasure of a glossy tourist trap' and 'the obliteration of made-for-social-media murals'. 
Many artists and street art commentators commended the actions of the paint-bombers as a wake up call to the issues that the lane presents.

'Hosier lane was refreshed by a crew of graft artists-probably the best project I've seen there for ages' (Sunshine 2020).

\section{Conclusion}

Soja (2009, p.3) explains, 'It is relatively easy to discover examples of spatial injustice descriptively, but it is much more difficult to identify and understand the underlying processes producing unjust geographies'. In this context, the limitations of this research have been that the stories have not been explored in depth and most likely more stories could have been revealed through interviews. More detailed research into the lanes could reveal underlying structures and thus recommendations for changes towards making lanes more democratically accessible.

Buckley draws our attention to the important role that marking our city walls has alongside the urge of authorities to clean and clear the 'unwanted'.

'Everyone is required to engage with public space, but few have the legal right to impact it. The appearance of, surfaces within, and images in our cities articulate our socio-political, legal and cultural make-up. Blank walls, locked gates, neat lawns, paste-ups, tags, murals and advertising bollards are neither aesthetically nor politically neutral. Unauthorised street art makes an important and politically charged contribution. It is direct democracy exercised over the appearance of public space and changes both the appearance of a wall or building and the experience of the society in which it is encountered' (Buckley 2020B).

What is important about the lanes is that they operate so publicly and are places which are used to debate and argue issues regarding public space. These debates are physically played out through the social actions of humans and the physical spaces in the lanes. What Hosier and Rutledge lanes offer us is the starkness of disparity. The clear and well-documented contradictory stories of: who gets to paint and how long their works stay there; the competing interests in public space, demonstrated by who makes money out of the lanes; and, who is forced to leave their home for economic interests.

Deutsche argues that 'the public sphere remains democratic only insofar as its exclusions are taken into account and open to contestation' (Deutsche 1996, p. 289). Contestation and argument over public space can be seen as positive, as integral and healthy signs of democracy (Mouffe 2007). It is the place of Hosier and Rutledge lanes, through their popularity and limelight due to illegal (but encouraged) acts, which raise the cusp where the many sides of these debate can be more fully seen.

Now, I no longer celebrate my chunks of peeled paint from Rutledge Lane as symbols of access for everyone but as a cusp, where the sharpest edges of competing ideas come together to be revealed and debated. 


\section{References}

ABC News 2020, 'Melbourne's Hosier Lane street art, graffiti, painted over in weekend 'vandalism' attack', <https://www.youtube.com/watch?v=8Fi6T3jdKFw>.

Allaoui, T 2016 'CCTV Must be Part of the Art', Herald Sun, 23 August, $<$ https://infoweb-newsbank-com.ezproxy-f.deakin.edu.au/resources/doc/nb/ news/15EECFB906B4FEC8? $\mathrm{p}=\mathrm{AUNB}>$.

Brown, A 2010, Recommendations for Culturally significant graffiti: Advice for the department of planning and community development, City of Yarra, <https://www. scribd.com/document/144055996/Recommendations-on-Culturally-SignificantGraffiti>.

Buckley, E 2020A, 'Outrage over Hosier Lane 'vandalism' completely misses the point', Sydney Morning Herald, 11.2.2020, <https://www.smh.com.au/national/victoria/ outrage-over-hosier-lane-vandalism-completely-misses-the-point-20200211-p53zph. html>.

Buckley, E, 2020B, 'The outrage on Hosier Lane and who has the right to the city', Overland, 13.2.20, <https://overland.org.au/2020/02/the-outrage-on-hosier-lane-andwho-has-the-right-to-the-city/>.

CDH, 2013, 'Notes on the commodification of street art', Art Monthly Australia, September 2013, <http://www.cdh-art.com/Writing/CDH\%20AMA\%20Notes\%20 on $\% 20$ the $\% 20$ commodification $\% 20$ of $\% 20$ street $\% 20$ art.pdf>.

City of Melbourne, 'Hosier and Rutledge Lanes Improvement Project Final report', $<$ https://hosierrutledge.files.wordpress.com/2014/10/com_service_prod-8787875-v1hosier_and_rutledge_lanes_improvement_project_final_report_-_october_2014.pdf>.

Combat Wombat 2016, 'Homeless Improvements' (film), Youtube, <https://www.youtube. $\mathrm{com} /$ watch?v=zR5a5Y3g4AY>.

Conklin, T 2020, 'Street Art, Ideology, and Public Space' (Masters Thesis), Portland University, <https://www.academia.edu/3258603/Street_Art_Ideology_and_ Public_Space_-_Masters_Thesis_-_Urban_Studies?auto=download\&email_work_ card=download-paper $>$.

Deutsche, R 1996, Evictions: Art and Spatial Politics, The MIT Press, Cambridge, Massachusetts.

Hillary, F \& Sumartojo, S 2014, 'Empty-Nursery Blue: On Atmosphere, Meaning and Methodology in Melbourne Street Art', Public Art Dialogue, 4:2, 201-220, <http:// dx.doi.org/10.1080/21502552.2014.936686>.

Francis, H 2017 'Street artists snub Hosier Lane over homeless eviction', Sydney Morning Herald, July 18, 2017, <https:/www.smh.com.au/entertainment/art-and-design/ archibald-prize-entry-highlights-plight-of-melbournes-homeless-street-artists-20170718gxdejo.html>.

Gralińska-Toborek, A 2016, 'Street Art and Space', Aesthetic Energy of the City: Experiencing Urban Art and Space, Agnieszka Gralińska-Toborek, Wioletta Kazimierska-Jerzyk (eds.), Wydawnictwo Uniwersytetu Łódzkiego, Poland. 
Hickey, A 2010, 'When the Street Becomes a Pedagogue', Sandlin, JA, Schultz, B \& Burdick, J (eds.), Handbook of Public Pedagogy: Education and Learning Beyond Schooling, Routledge, New York.

Holsworth, M 2020A, 'Hosier Lane 2020' (Blog Post 22.1.29), viewed 5.7.20, <https:// melbourneartcritic.wordpress.com/2020/01/22/hosier-lane-january-2020/>.

Holsworth, M 2020B, 'A decade ago in Hosier lane' (Blog Post, 26.3.20), Black Mark Melbourne art and culture critic, viewed 5.7.20,

<https://melbourneartcritic.wordpress.com/2020/03/26/a-decade-ago-in-hosier-lane/>.

Holsworth, M 2016, 'Homeless at Hosier Lane' (Blog Post), Black Mark Melbourne art and culture critic, viewed 5.7.20, <https://melbourneartcritic.wordpress. com/2016/10/22/homeless-hosier-lane/>.

Honig, C 2017. 'In Melbourne, Again: Artists Turn Vandalism into Art', CITI.IO, 3 February,

<https:/citi.io/2017/02/03/in-melbourne-again-artists-turn-vandalism-into-art/>.

Honig C, Feb 4, 2017 'In Melbourne, Again: Artists Turn Vandalism into Art' first published in The Conversation,

$<$ https://theconversation.com/some-rough-sleepers-are-attracting-tourists-with-their-streetart-71983>

Hosier lane Inc. (wordpress site), viewed 23.5.20, <https://hosierrutledge.wordpress.com/>.

Irving, S 2020, 'Guerrilla painters in Melbourne's Hosier Lane expose our hypocritical ideas about street art', The Guardian 12.2.2020, <https://www.theguardian.com/ artanddesign/2020/feb/12/guerrilla-painters-in-melbournes-hosier-lane-expose-ourhypocritical-ideas-about-street-art $>$.

Irving, S (no date), 'Forget Save Hosier Lane, Tear That Sucker Down', Acclaim Magazine, viewed 8.7.2020, <https://acclaimmag.com/art/forget-save-hosier-lane-tear-sucker/>.

Jopp, R 2017, 'Melbourne's love-hate relationship with being Australia's 'street art capital', The Conversation June 8, 2017, <https://theconversation.com/melbournes-love-haterelationship-with-being-australias-street-art-capital-78177>.

Low, N 2006, 'Clean Project 2006' (web page), March 21, 2006, viewed 8.7.2020, $<$ https://www.dislocated.org/?p=90>.

McAlpine, L 2016, 'Why might you uses narrative methodology? A story about narrative', East Haridusteaduste Ajarkiri (Estonian Journal of Education), No. 4(1), 32-57. 2016, <http://dx.doi.org/10.12697/eha.2016.4.1.02b>.

Miller, N 2020, 'Art is supposed to provoke emotion': Hosier Lane paint-bomber speaks out', Sydney Morning Herald 12.2.2020, <https://www.smh.com.au/culture/art-anddesign/art-is-supposed-to-provoke-emotion-hosier-lane-paint-bomber-speaks-out20200211-p53zqu.html>.

McInley, D, 2006, 'Next Wave taken to the streets', Real Time, http://www.realtimearts. net/article/73/8106 